ResearCh Article

Published September 15, 2016

\title{
EPITOPE CAPSID-INCORPORATION: A New Effective Approach for Vaccine Development for Chagas Disease
}

\section{AUTHORS}

Qiana L. Matthews ${ }^{\star 1,2}$, Anitra L. Farrow ${ }^{\star 2}$, Girish Rachakonda ${ }^{3}$, Linlin Gu ${ }^{4}$, Pius Nde ${ }^{3}$, Alexandre Krendelchtchikov ${ }^{2}$, Siddharth Pratap ${ }^{3}$, Shruti S. Sakhare ${ }^{3}$, Steffanie Sabbaj ${ }^{2}$, Maria F. Lima ${ }^{3}$, Fernando Villalta ${ }^{3 *}$

\section{AFFILIATED INSTITUTIONS}

${ }^{1}$ Department of Biological Sciences, Alabama State University, Montgomery, Alabama ${ }^{2}$ Department of Medicine, Division of Infectious Diseases, University of Alabama at Birmingham, Alabama

${ }^{3}$ Department of Microbiology and Immunology, School of Medicine, Meharry Medical College, Nashville, Tennessee

${ }^{4}$ Division of Pulmonary, Allergy and Critical Medicine, Department of Medicine, University of Alabama at Birmingham, Birmingham, Alabama

\section{CORRESPONDING AUTHOR}

Qiana L Matthews

Alabama State University

Life Science Building Room 313

Montgomery, AL 36104

qmatthews@alasu.edu

* These authors contributed equally to this work.

\section{RUNNING TITLE}

New Approach for Chagas Vaccine

\section{DOI}

10.20411/pai.v1i2.114 


\section{ABSTRACT}

Background: Previously we reported that a hexon-modified adenovirus (Ad) vector containing the invasive neutralizing epitope of Trypanosoma cruzi (T. cruzi) trypomastigote gp83 (Ad5-gp83) provided immunoprotection against T. cruzi infection. The purpose of this work was to design an improved vaccine for T. cruzi using a novel epitope capsid incorporation strategy. Thus, we evaluated the immunoprotection raised by co-immunization with Ad5-gp83 and an Ad vector containing an epitope (ASP-M) of the T. cruzi amastigote surface protein 2.

Methods: Protein IX (pIX)-modified Ad vector (Ad5-pIX-ASP-M) was generated, characterized, and validated. C3H/He mice were immunized with Ad5-pIX-ASP-M and Ad5-gp83 and the cell-mediated responses were evaluated by enzyme-linked immunospot (ELISPOT) assay and intracellular staining. Immunized mice were challenged with T. cruzi to evaluate the vaccine efficacy.

Results: Our findings indicate that Ad5-pIX-ASP-M was viable. Specific CD8 ${ }^{+} \mathrm{T}$-cell mediated responses prior to the challenge show an increase in IFN $\gamma$ and TNF $\alpha$ production. A single immunization with Ad5-pIX-ASP-M provided protection from T. cruzi infection, but co-immunizations with Ad5-pIX-ASP-M and Ad5-gp83 provided a higher immunoprotection and increased survival rate of mice.

Conclusions: Overall, these results suggest that the combination of gp83 and ASP-M specific epitopes onto the capsid-incorporated adenoviruses would provide superior protection against Chagas disease as compared with Ad5-gp83 alone.

Keywords: Chagas disease; T. cruzi vaccine constructs; epitope-capsid incorporation; trypomastigote gp83 neutralizing epitope; amastigote surface protein 2 epitope; co-immunization, immunoprotection

\section{INTRODUCTION}

Chagas disease is a neglected disease that affects 8-15 million people in Latin America. The disease has now spread globally due to international human migration, and it is becoming a new worldwide health challenge $[1,2]$. Currently, 2-7 million people with Chagas disease live in North America [ 3 ]. Chagas-infected individuals represent a $\$ 7$ billion/year burden worldwide [4]. The existing drugs are toxic and have limited efficacy and recent clinical trials with new drugs (posaconazole and ravuconazole) failed $[\underline{5}, \underline{6}]$. Rational drug discovery based on the structure of drug targets for Trypanosoma cruzi (T. cruzi) has yielded two promising drugs (VNI and VFV), which have not yet entered clinical trials [7-10].

Innate and adaptive immunity play important roles in parasite growth control during the acute infection; however, the parasite suppresses the immune system, allowing the establishment of the destructive chronic phase. To date, no preventive or therapeutic human vaccines have entered clinical trials. Thus, there is a desperate need for a safe and effective vaccine to protect the $40-100$ million individuals at risk. Defined molecular vaccines for Chagas disease would be ideal to overcome controversial potential molecular mimicry and immunosuppression caused by the parasite [9-17]. 
Efforts to generate experimental vaccines using Chagas animal models with inactivated and attenuated parasites [18], purified proteins, recombinant proteins DNA, and, more recently, replication-deficient bacteria and recombinant vectors were reported [19-21]. However, progress made with defined molecular vaccines is minimal.

Recently, we reported a novel strategy for generating a new effective vaccine for Chagas disease consisting of incorporating a T. cruzi epitope (gp83) into the capsid of modified Adenovirus-5 (Ad5) [22]. We found that mice immunized with this construct provided protection against $T$. cruzi by reducing infection, inducing neutralizing antibodies, and increasing survival rates [22]. The surface glycoprotein 83 (gp83) is a trans-sialidase like molecule unique to invasive trypomastigotes and used as a ligand to attach to host cells and initiate infection [23]. Blocking gp83 with MAb 4A4, which recognizes a gp83 epitope, neutralizes trypomastigote cellular infection [24]. Passive immunization with monovalent $4 \mathrm{~A} 4 \mathrm{Fab}$ fragments neutralizes T. cruzi infection in mice challenged with a lethal dose of trypomastigotes [23]. In efforts to continue the development of the most effective vaccine for T. cruzi, we extended our antigen capsid-incorporation strategy to include both a humoral and cellular response. To date, one of the most promising candidates for a Chagas disease vaccine has been the amastigote protein 2 (ASP-2) [25-29]. We reasoned that a vaccine including the gp83 neutralizing epitope and an epitope (ASP-M) of ASP-2 would provide additional significant protection by inducing neutralizing antibodies, beneficial $\mathrm{CD}^{+}$cellular responses, reduction of parasitism, and increased survival rate. Here, we provide evidence that the ASP-M epitope was incorporated into the capsid protein pIX of Ad5. We also confirmed that upon challenge with a lethal dose of trypomastigotes, the mice co-immunized with the gp83 neutralizing epitope, and the ASP-M epitope capsid-incorporated vector displayed a significant reduction in parasitemia, improvement of their survival rate by eliciting neutralizing antibodies and $\mathrm{CD}^{+} \mathrm{T}$ cells capable of stimulating CD107a, TNFa, and IFN $\gamma$ in response to the ASP-M epitope.

\section{METHODS}

\section{Cell Culture and Parasites}

Human embryonic kidney (HEK293) cells were obtained from and cultured in the medium recommended by the American Type Culture Collection (Manassas, VA).

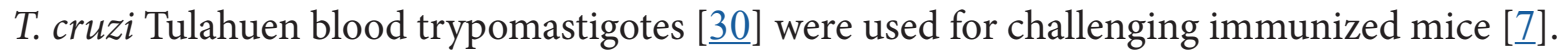
Trypomastigotes expressing green fluorescent protein (GFP) for cellular infection assays were generated as described [ $\underline{31}]$.

\section{Recombinant Adenoviral Construction}

Recombinant adenovirus with the T. cruzi ASP-M epitope as well as His genetically incorporated within Ad5 pIX was generated [32]. Briefly, the DNA sequence corresponding to the median immunodominant region of ASP-2 and $\mathrm{His}_{6}$ (24 amino acids) was generated by GenScript (Piscataway, NJ) and subcloned into the pIX shuttle vector to generate pIX-shuttle-ASP-M. The resulting plasmid was then digested with PmeI. The digested fragment containing the homologous recombination regions and the pIX gene were recombined through homologous recombination with an Ad5 backbone replacing the wildtype pIX gene. The recombination was performed in Escherichia coli BJ5183, leading to the identification of positive vector clones. 


\section{Rescue, Purification, and Titration of Recombinant Ad5 Vector}

To rescue the vector, the recombinant adenoviral genome was digested with PacI and transfected with PolyJet (SignaGen Laboratories) into the Ad5-E1-expressing HEK293 cells. Multi-step largescale propagations of recombinant Ad5 vector were performed after the vector was rescued. Viruses were purified by double $\mathrm{CsCl}$ ultracentrifugation. Physical titers, expressed as viral particles (VPs) per $\mathrm{mL}$, were measured at OD $260 \mathrm{~nm}$. Infectious particles (IPs) per $\mathrm{mL}$ were determined by tissue culture infectious dose $\left(\mathrm{TCID}_{50}\right)$ assay [33] .

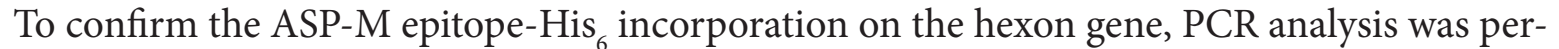
formed with the following primers: 5'- CAATTGGATTCTTTGACCC-3' and 5' AATTTGTCCCGTCTCCCATTCGGT-3'.

\section{Western Blot Analysis}

To analyze the ASP-M epitope and $\mathrm{His}_{6}$ expression, immunoblots of $5 \times 10^{9} \mathrm{VPs} /$ vector were probed with $\mathrm{His}_{6} \mathrm{MAb}$ and developed with HRP-conjugated goat anti-mouse antibody. Proteins were detected by 3'3'-diaminobenzidine [33].

\section{Whole Virus ELISAs}

To investigate the exposure-display of ASP-M epitope and His ${ }_{6}$ on the surface of the capsid, whole virus enzyme-linked immunosorbent assays (ELISAs) were performed [34]. Different amounts of the Ad5-pIX-ASP-M or Ad5 (control) were immobilized onto 96-well plates, incubated with $\mathrm{His}_{6} \mathrm{MAb}$, HRP-conjugated goat anti-mouse antibody, developed with peroxidase substrate and measured at OD $450 \mathrm{~nm}$.

\section{Mice Immunizations}

$\mathrm{C} 3 \mathrm{H} / \mathrm{He}$ mice (6 weeks) were immunized with either Ad5 (control) or Ad5-pIX-ASP-M to determine the ASP-M-specific immunogenicity using IACUC approved protocols. Mice groups were immunized intramuscularly with the corresponding vector $\left(1 \times 10^{10} \mathrm{VP} /\right.$ mouse $)$ at each timepoint, with a two-week interval between prime, boost, and reboost.

\section{IFNy ELISPOT Assays}

For IFN $\gamma$ enzyme-linked immunospot (ELISPOT) assays, groups of mice were immunized as described previously. Two weeks after boost immunization, peripheral blood mononuclear cells (PBMCs) were collected. All assays were carried out using Mouse IFN $\gamma$ ELISPOT Ready-SetGo Kit (eBioscience, San Diego, CA). Nitrocellulose plates were coated with $10 \mu \mathrm{g} / \mathrm{mL}$ of IFN $\gamma$ capture antibody. PBMCs were seeded at $2 \times 10^{5}$ cells/well in triplicate and stimulated with ASP-M peptide $(10 \mu \mathrm{g} / \mathrm{mL})$ or media alone. For positive control, PBMCs were stimulated with $10 \mathrm{ng} / \mathrm{mL}$ phorbol 12- myristate 13-acetate (PMA) plus $500 \mathrm{ng} / \mathrm{mL}$ ionomycin. After incubation, cells were removed and spot forming cells (SFCs) were enumerated using CTL ImmunoSpot S6 Ultra V Analyzer.

\section{Intracellular Cytokine Staining Assay}

Splenocytes from C3H/He immunized mice were treated with ACK lysing buffer (Thermo Fisher Scientific, Waltham, MA ) and the cell concentration was adjusted to $2 \times 10^{6} \mathrm{cells} / \mathrm{mL}$ in $500 \mu \mathrm{l}$ 
of cell culture medium containing CD107a-FITC ( $2 \mathrm{mg} / \mathrm{mL})$, and Golgi stop (monensin) [10 $\mu \mathrm{g} /$ $\mathrm{mL}$ ], (BD Biosciences, San Jose, CA). The ASP-M peptide, TEWETGQI $(10 \mu \mathrm{M})$ was added to the experimental tubes; PMA $(50 \mathrm{ng} / \mathrm{mL})$ and ionomycin $(1 \mu \mathrm{g} / \mathrm{mL})$ were added to the positive control tubes and incubated for 6 hours. Cells were incubated with surface antibodies and stained with CD3-Pacific Blue hamster-anti-mouse (BD Biosciences, San Jose,CA), CD4-APC-eFluor 780 anti-mouse (eBioscience, San Diego, CA), and CD8-PE rat-anti-mouse (BD Biosciences, CA) to determine the surface phenotype. Cells were permeabilized with Cytofix/Cytoperm (BD Biosciences, CA), stained for intracellular markers TNF $\alpha$-PE-Cy7 rat-anti-mouse and IFN $\gamma$-Alexa Fluor 700-rat-anti-mouse (BD Biosciences, CA), and fixed in 1\% formalin. At least $100000 \mathrm{CD} 3^{+}$events were acquired from each sample using a Becton Dickinson LSR II flow cytometer (BD Biosciences, CA) and data was analyzed using FlowJo v10 software (Tree Star, Ashland, OR). Lymphocytes were analyzed based on forward and side scatter profiles. Gates were set based on the media control and applied to all samples from the same individual for each time point. Cytokines produced were measured from the $\mathrm{CD}^{+} \mathrm{CD}^{+}$or the $\mathrm{CD}^{+} \mathrm{CD}^{+}$gates relative to the media control values.

\section{Mice Challenge}

Groups of 5 female $\mathrm{C} 3 \mathrm{H} / \mathrm{He}$ mice (Jackson Laboratory, 6-week-old, same weight) immunized with Ad5 (control), Ad5-pIX-ASP-M, Ad5-gp83 or with Ad5-gp83 + Ad5-pIX-ASP-M (as described previously) were challenged intraperitoneally with a lethal dose of $5 \times 10^{3}$ blood trypomastigotes of the clone 20A of the Tulahuen strain of T. cruzi using Institutional Animal Care and Use Committee-approved protocols. Parasitemia was monitored in $5 \mu \mathrm{l}$ of mouse tail blood [18]. The survival rate was recorded.

\section{Neutralization Assay}

Mice immunized with Ad5-pIX-ASP-M, Ad5-gp83, Ad5-gp83 + Ad5-pIX-ASP-M or nonimmunized control mice were bled before T. cruzi challenge to obtain serum to evaluate the ability of antibodies to neutralize T. cruzi infection of cardiomyocytes [22]. GFP-expressing trypomastigotes were pre-incubated with sera from immunized or nonimmunized control mice for 30 minutes at $37^{\circ} \mathrm{C}$ and exposed in triplicate to cardiomyocyte monolayers at 10 parasites/cell ratio [12]. Parasite multiplication within cell monolayers at 72 hours was determined fluorometrically as relative fluorescence units (RFU) [31, 35]. To microscopically visualize the effect of neutralizing antibodies on cellular infection, we repeated the aforementioned experimental conditions. Cells were fixed and stained with 4', 6-diamidino-2-phenylindole (DAPI) and Alexa Fluor 546 phalloidin for fluorescence confocal microscopy evaluation of infection $[\underline{7}, \underline{35}]$.

\section{STATISTICAL ANALYSES}

Statistical analyses were performed by the nonpaired 2-tailed Student's t-test, assuming equal variance and analysis of variance (ANOVA) when appropriate. Statistical significance was defined as $P<0.05$.

\section{RESULTS}

\section{Construction and Characterization of Ad5 Vector with Modified Protein IX}

Our recent antigen capsid-incorporation studies have utilized the Ad5 hexon. In this body of 
work, we explored the use of antigen capsid-incorporation by modifying Ad5 pIX as a novel tool for vaccine development. The modified Ad vector, referred to as Ad5-pIX-ASP-M (Figure 1A), contains the immunodominant $\mathrm{CD}^{+} \mathrm{T}$-cell epitope (TEWETGQI) from the medial region of ASP-2 [ㅌ6] as well as $\mathrm{His}_{6}$ and Flag (DYKDDDDK) epitopes incorporated into the minor Ad capsid protein IX (pIX) (Figure 1A, construct 3). The control vector (Ad5) and Ad5-gp83 vector depicted in Figure 1A were generated as described [22]. Ad5-pIX-ASP-M was rescued and upscaled as described [33]. The physical and infectious titers were determined to test the stability of the Ad5-pIX-ASP-M vector. Based on those two assays, the viral particle/infectious particle (VP/IP) ratio was determined (Figure $1 \mathrm{~B}$ ). A normal VP/IP ratio of unmodified Ad ranges from $\sim 10-30$ [33]. The VP/IP ratios for Ad5 and Ad5-gp83 were 30 and 60, respectively. For Ad5-pIX-ASP-M, the VP/IP ratio was 19. Based on these observations, the insertion of the ASP-FLAG-His epitope did not affect vector stability.

A.

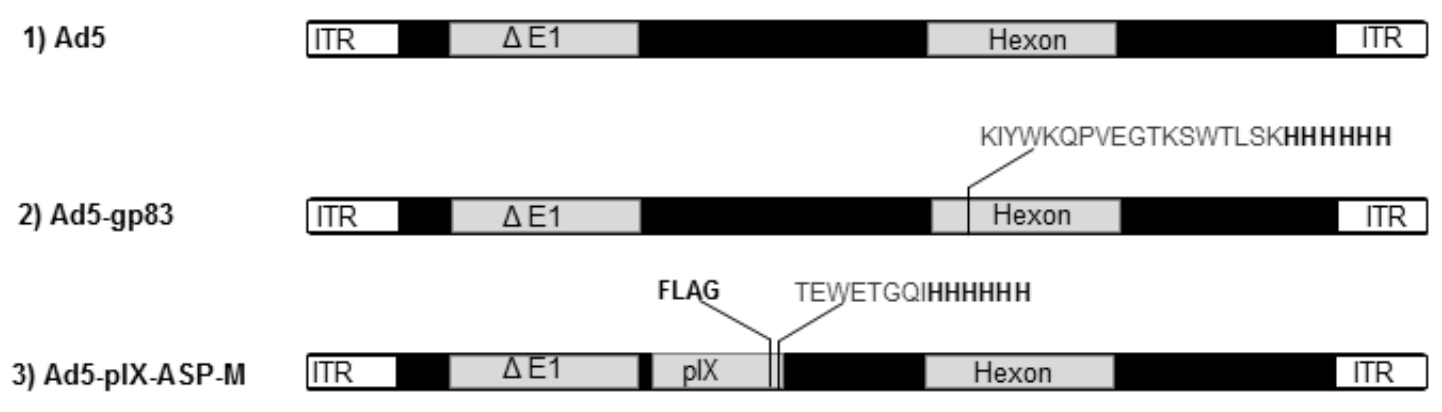

B.

\begin{tabular}{|c|c|c|c|}
\hline Ad5 Vectors & Viral Particles (VP) & Infectious Particles (IP) & VP/IP \\
\hline Ad5 & $2.38 \times 10^{12} \mathrm{VP} / \mathrm{ml}$ & $7.9 \times 10^{10} \mathrm{IP} / \mathrm{ml}$ & 30 \\
\hline Ad5-gp83 & $1.5 \times 10^{12} \mathrm{VP} / \mathrm{ml}$ & $2.5 \times 10^{10} \mathrm{IP} / \mathrm{ml}$ & 60 \\
\hline Ad5-plX-ASP-M & $1.5 \times 10^{12} \mathrm{VP} / \mathrm{ml}$ & $7.9 \times 10^{10} \mathrm{IP} / \mathrm{ml}$ & 19 \\
\hline
\end{tabular}

Figure 1. Schematic representation of the T. cruzi ASP-M epitope and His ${ }_{6}$ epitope genetically incorporated into the pIX of Ad5 and T. cruzi gp83 epitope incorporated into the hexon of Ad5 (A), and virological properties of vectors (B). (A): (1) Ad5, a replication-defective adenovirus with wildtype pIX. (2) Ad5-gp83, Ad5 replication-defective genome containing an incorporated neutralizing T. cruzi trypomastigote gp83 epitope within the hexon locale. (3): Ad5-ASP-M, Ad5 replication-defective genome containing an incorporated T. cruzi amastigote ASP-M epitope within the pIX locale. (B): VP/IP ratio.

PCR analysis of the vector confirmed the antigen capsid-incorporation. As shown in Figure 2A left panel lane 3, the amplification product of expected size (165 bp) was found for Ad5-pIXASP-M and no amplification in the Ad5 control lane was seen (Figure 2A, left panel, lane 2). For the pIX-specific PCR, Ad5 yielded a 272 bp band (Figure 2A, right panel, lane 2) whereas Ad5- 
pIX-ASP-M yielded a higher band at 323 bp indicating the incorporation of the ASP-FLAG-His ${ }_{6}$ DNA within the pIX region (Figure 2A, right panel, lane 3).

Ad5-pIX-ASP-M contains a protein band that was detected with Flag HRP antibody as $18.5 \mathrm{kDa}$ (Figure 2B, left panel, lane 3), as expected for the ASP-FLAG-His ${ }_{6}$ incorporation within pIX.

Ad5-pIX-ASP-M displayed a similar protein profile as the control Ad5 vector (Figure 2B, right panel), indicating that the ASP-FLAG-His ${ }_{6}$ incorporation did not affect the expression of any of the Ad capsid proteins.

A.

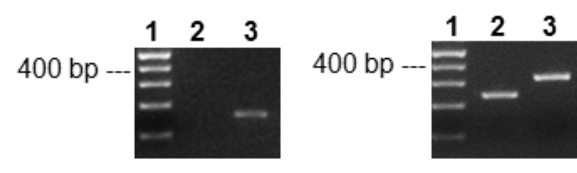

c.

B.
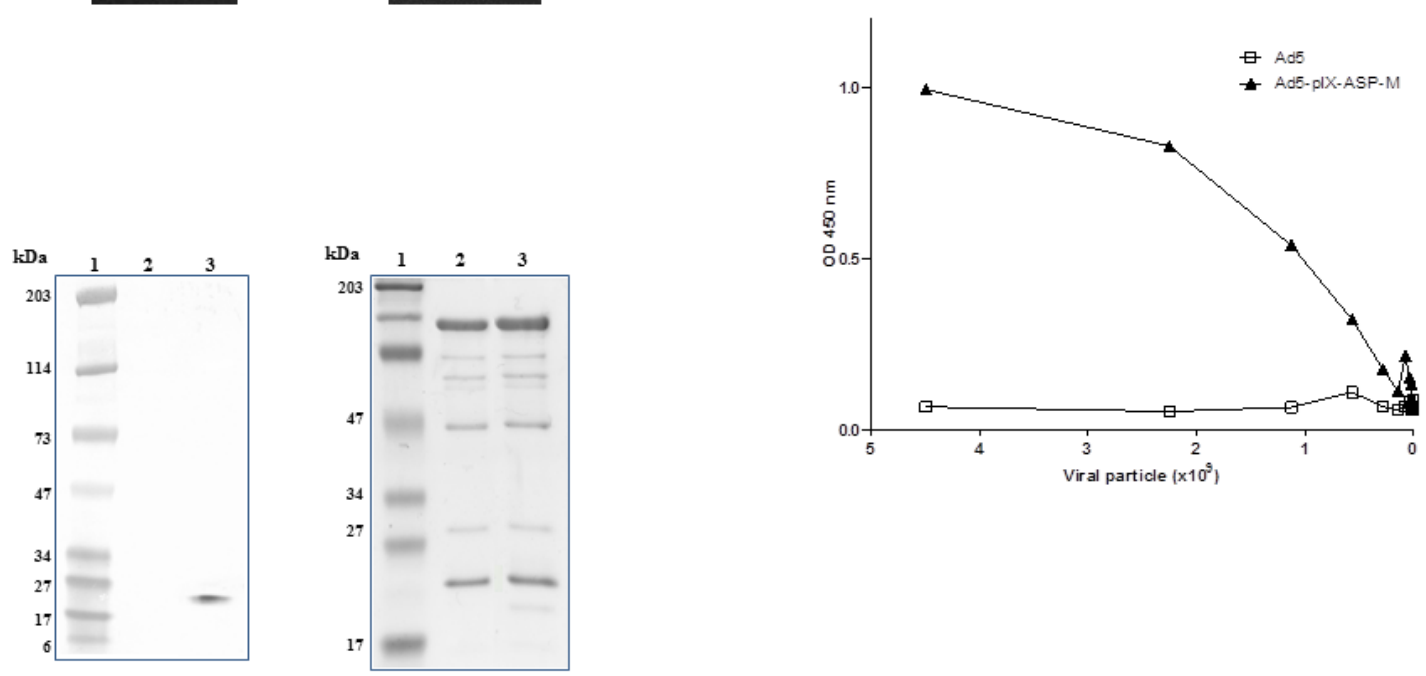

Figure 2. Verification of epitope capsid-incorporation into pIX of Ad5 (A and B) and epitope exposure on the virion surface (C). (A): left panel A, pIX-specific PCR primers confirmed the presence of the ASP-M DNA within the pIX locale. Lane 1, DNA ladder; lane 2, Ad5; and lane 3, Ad5-pIX-ASP-M. Right panel A, T. cruzi-His ${ }_{6}$-specific primers confirmed the incorporation of ASP-M and His ${ }_{6}$ DNA. Lane 1, DNA ladder; lane 2, Ad5; and lane 3, Ad5-pIX-ASP-M. (B): Left panel B, Immunoblots confirmed the presence of $\mathrm{His}_{6}$ incorporation within the modified vector. Protein marker (lane 1), Ad5 (lane 2), and Ad5-pIX-ASP-M (lane 3). Right panel B, Coomassie blue staining of the Ad5 vectors. Protein marker (lane 1), Ad5 (lane 2), and Ad5-pIX-ASP-M (lane 3). (C): Varying amounts (starting at $4.5 \times 10^{9} \mathrm{VP} / \mathrm{mouse}$ ) of Ad5 or Ad5-pIX-ASP-M were immobilized onto the wells of ELISA plates, incubated with His ${ }_{6}$ MAb and HRP-conjugated secondary antibody and the OD was read at $450 \mathrm{~nm}$.

\section{Incorporated ASP Antigen Accessible on the Surface of the Virion}

ELISA assays confirmed that the T. cruzi antigen was virion surface accessible (Figure 2C). This is critical with respect to pIX-modified vectors because Ad vectors can be produced that are pIX defective [37] and in order to generate an appropriate immune response, the pIX-ASP protein must be virion surface exposed. Dose-dependent binding of the Ad5-pIX-ASP-M vector was seen, 
demonstrating that the T. cruzi antigen was capsid-incorporated and surface exposed, whereas no binding was seen in response to Ad5 control.

\section{Cellular Immune Response of Mice Immunized with the Modified Ad5 Vector}

We assessed whether immunization with Ad5-pIX-ASP-M could elicit a cell-mediated T. cruzi-specific immune response. Two weeks after homologous vector reboost immunization, as shown in the immunization schedule (Figure 3A), $\mathrm{C} 3 \mathrm{H} / \mathrm{He}$ mice PBMCs were evaluated for IFN $\gamma$ production by ELISPOT following stimulation with mitogen (PMA/ionomycin), or ASP-M

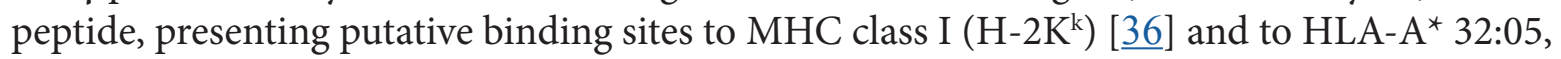
HLA-A*32:08, HLA-A* 02:87, HLA-A*32:06, and HLA-A*32:20, that we identified using NetMHCpan [37], which are alleles frequent in Hispanic populations (www.allelefrequencies.net), and to 10 additional HLA-A ${ }^{\star} 02$ and 32 alleles. ELISPOT analysis revealed measurable numbers of spot forming cells (SFCs) in the PBMCs stimulated with mitogen and the ASP-M peptide (Figure 3). Mitogen stimulated PBMCs produced greater than 1000 SFCs (Figure 3B). PBMCs from mice immunized with Ad5-pIX-ASP-M and stimulated with TEWETGQI produced an average of 1676 SFCs whereas PBMCs from Ad5 immunized mice produced less than 5 SFCs (Figure 3C). The significant differences in the number of IFN $\gamma$ producing cells in the mice immunized with Ad5pIX-ASP-M compared with the mice immunized with Ad5 $(P<0.001)$ allowed us to conclude that Ad5-pIX-ASP-M elicit a strong cell-mediated immune response. Two weeks after homologous vector reboost immunization; splenocytes from a subset of immunized mice were stimulated with mitogen or ASP-M peptide and assessed for intracellular staining of IFN $\gamma$ and TNFa cytokines and for the surface mobilization of CD107a, a marker of T-cell degranulation. Representative histograms depicting the gating strategy for the detection of TNFa from both $\mathrm{CD}^{+}$and $\mathrm{CD}^{+} \mathrm{T}$ cells are shown in Figure 4A and 4B. There was no difference in the frequencies of CD4 ${ }^{+} \mathrm{T}_{\text {lym- }}$ phocytes producing CD107a, IFN $\gamma$, and TNFa in response to the ASP-M peptide in the Ad5-pIXASP-M immunized mice compared with the Ad5 immunized mice (Figure 4C), indicating that the ASP-M epitope is MHC class I CD8 restricted. However, we observed substantially higher production of CD107a $(P<0.001), \operatorname{IFN} \gamma(P<0.01)$, and TNFa $(P<0.01)$ secretion in response to the ASP-M peptide from $\mathrm{CD}^{+} \mathrm{T}$-cells isolated from Ad5-pIX-ASP-M immunized mice compared with the CD8 ${ }^{+}$T-cells from Ad5 immunized mice (Figure 4C).

Similar results were observed when $\mathrm{CD}^{+}$and $\mathrm{CD} 8^{+} \mathrm{T}$ cells were analyzed for dual effector molecule secretion $\left(\mathrm{IFN} \gamma^{+} \mathrm{CD} 107 \mathrm{a}^{+}\right.$and $\mathrm{TNFa}^{+} \mathrm{CD} 107 \mathrm{a}^{+}$). Representative histograms of the double-positive gating for IFN $\gamma^{+} \mathrm{CD} 107 \mathrm{a}^{+}$cells are shown in Figure 4(D and E). There was no significant difference in the percentage of $\mathrm{CD} 4^{+} \mathrm{IFN} \gamma^{+} \mathrm{CD} 107 \mathrm{a}^{+}$or $\mathrm{CD} 4^{+} \mathrm{TNFa}^{+} \mathrm{CD} 107 \mathrm{a}^{+}$cells in Ad5-pIX-ASP-M immunized mice compared with the Ad5 immunized mice (Figure 4F). There was a significant difference in the frequency of $\mathrm{CD}^{+} \mathrm{T}$ cells double-positive for IFN $\gamma^{+} \mathrm{CD} 107 \mathrm{a}^{+}$ secretion $(P<0.01)$ as well as the frequency of $\mathrm{TNFa}^{+} \mathrm{CD} 107 \mathrm{a}^{+}$secreting cells $(P<0.01)$ in the immunized mice compared with the control group (Figure $4 \mathrm{~F}$ ). These results demonstrate that the IFN $\gamma$ detected in our previous ELISPOT assays was secreted by $\mathrm{CD}^{+} \mathrm{T}$ cells. 
A.

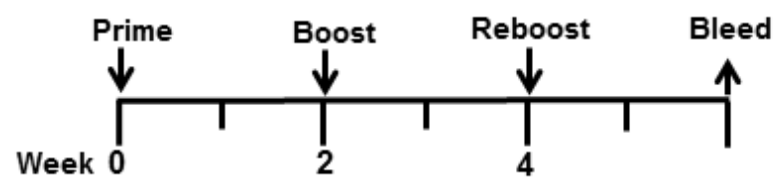

B.

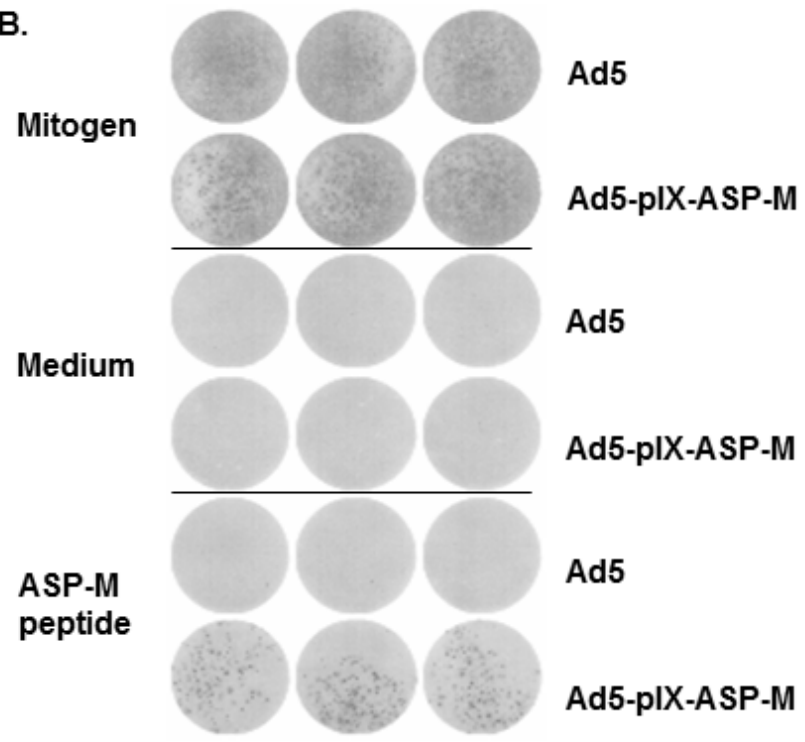

c.

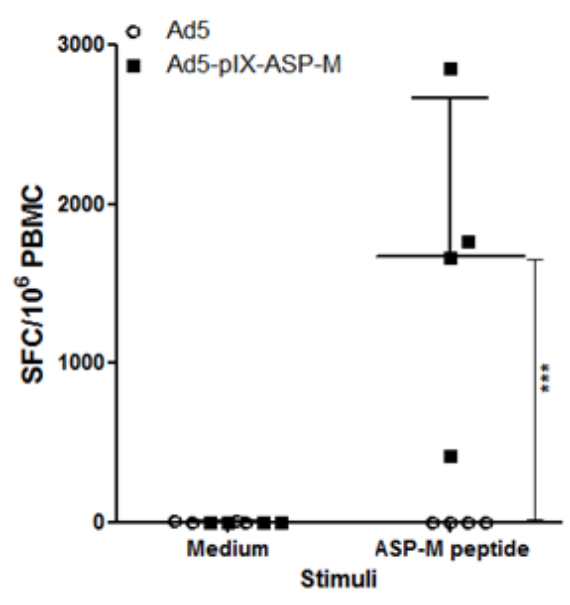

Figure 3. Immunization with Ad5-pIX-ASP-M induces IFN $\gamma$-secreting cells. (A): Animals were immunized every 2 weeks for a total of 3 immunizations. PBMCs were obtained 2 weeks following the final immunization and were assayed by enzyme-linked immunosorbent spot (ELISPOT). (B): A representative ELISPOT. Well images of $4 \times 10^{5}$ PBMCs cultured with media, mitogen (PMA/ionomycin), or ASP-M peptides. (C): Analysis of ASP-M IFN $\gamma$-producing cells in PBMC upon immunization with Ad5-pIX-ASP-M. Each square or dot represents the mean number of IFN $\gamma$ secreting cells per $10^{6} \mathrm{PBMC}$ for an individual mouse. $\left.{ }^{* * *}\right)=P<0.001$. 
A. CD4+

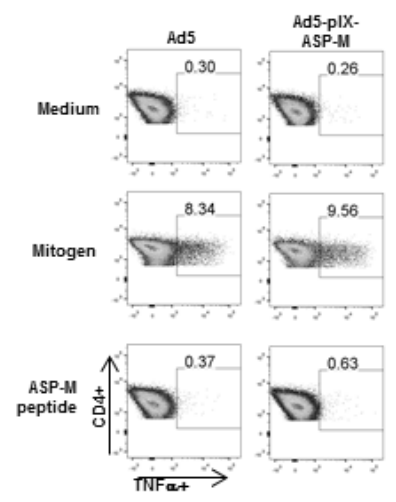

D. CD4+

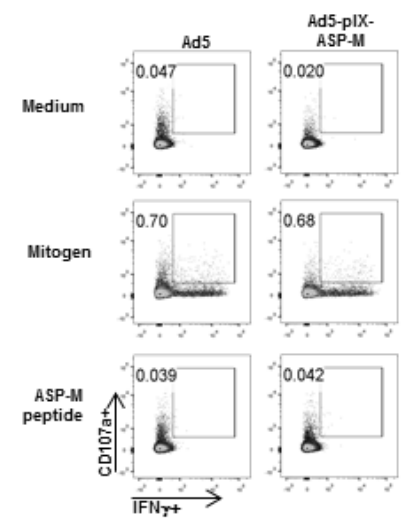

B. CD8+

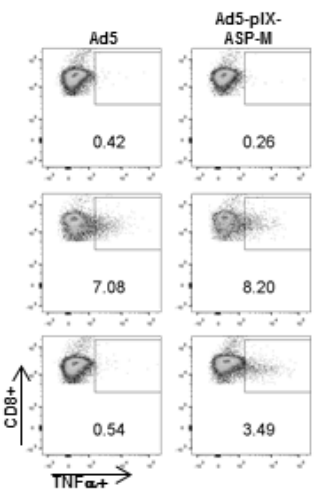

E. CD8+

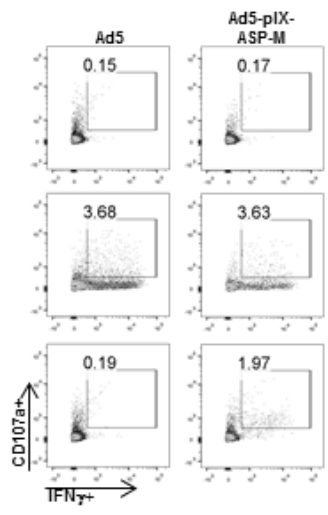

C.

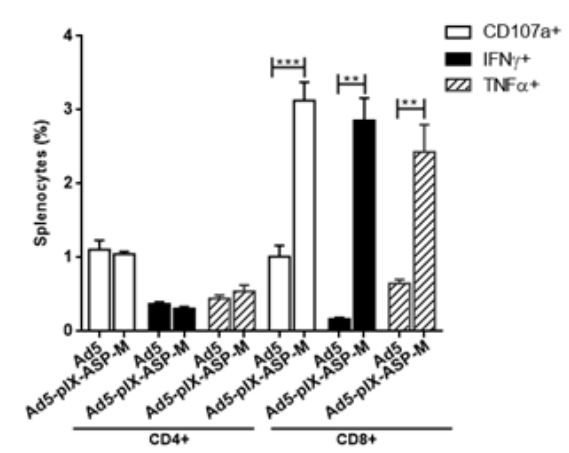

F.

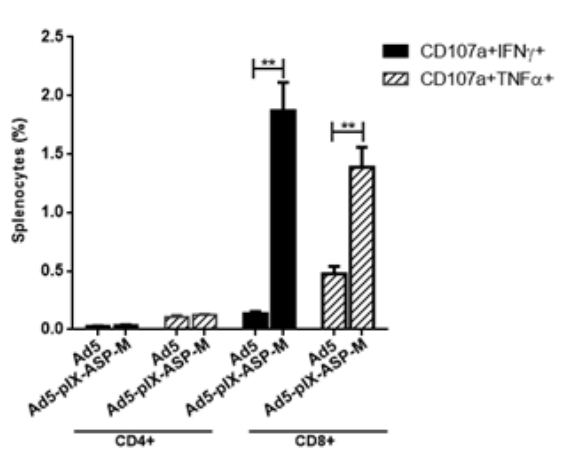

Figure 4. Frequencies of ASP-specific T-cell responses in immunized mice. Representative flow cytometric analysis of intracellular staining for IFN $\gamma$ and TNFa production by ASP-M-specific $\mathrm{CD} 4^{+}$and $\mathrm{CD}^{8}+\mathrm{T}$-cells memory cells. C3H/He mice were immunized with Ad5 or Ad5-pIX-ASP-M as described in Materials and Methods. Two weeks after the last immunization, splenocytes harvested from a subset of mice were stimulated with anti-CD107a and GolgiStop in the presence or absence of ASP-M peptide. After 6 hours, cells were incubated with anti-CD3, anti-CD4, and anti-CD8. Next the cells were permeabilized and fixed, then stained with anti-TNFa, and anti-IFN $\gamma$. Cells were gated by side scatter area (SSC-A); forward scatter area (FSC-A); and gated for $\mathrm{CD}^{+} \mathrm{CD}^{+}$or $\mathrm{CD}^{3+} \mathrm{CD}^{8+} \mathrm{T}$ lymphocytes. (A): Representative flow cytometry plots of $\mathrm{TNF}^{+}$by $\mathrm{CD}^{+} \mathrm{T}$ cells from the spleens of the immunized mice; (B): Representative flow cytometry plots of $\mathrm{TNF}^{+}$by $\mathrm{CD} 8^{+} \mathrm{T}$ cells from the spleens of the immunized mice; (C): Histogram showing the percentage of $\mathrm{CD} 107 \mathrm{a}^{+}, \mathrm{INF}^{+}, \mathrm{TNFa}^{+}$production. The numbers represent the frequencies of cells stained for $\mathrm{CD}^{+} \mathrm{INF}^{+}, \mathrm{CD}^{+} \mathrm{TNFa}^{+}$or $\mathrm{CD}^{+} \mathrm{INF}^{+}, \mathrm{CD}^{+} \mathrm{TNFa}^{+}$. The results are presented as the mean \pm SEM frequencies of $\mathrm{CD}^{+}$or $\mathrm{CD}^{+}$cells for 4 mice. $\left.{ }^{* *}\right)=P<0.01$ and $\left(^{* *}\right)=P<0.001$. (D): Representative flow cytometry plots of $\mathrm{CD} 107 \mathrm{a}^{+} \mathrm{IFN} \gamma^{+}$produced by $\mathrm{CD} 4^{+} \mathrm{T}$ cells from the spleens of the immunized mice; (E): Representative flow cytometry plots of $\mathrm{CD} 107 \mathrm{a}^{+} \mathrm{IFN} \gamma^{+}$produced by $\mathrm{CD} 8^{+} \mathrm{T}$ cells from the spleens of the immunized mice; (F) Histogram showing the percentage of CD107a+IFN $\gamma^{+}$and $\mathrm{CD} 107 \mathrm{a}^{+} \mathrm{TNF}^{+}$production. The results are presented as the mean $\pm \mathrm{SEM}$ frequencies of $\mathrm{CD} 4^{+}$or $\mathrm{CD} 8^{+}$ cells for 4 mice. $\left(^{* *}\right)=P<0.01$. 


\section{Modified Ad5 Vectors That Induced Protective Immunity From T. Cruzi Infection}

$\mathrm{C} 3 \mathrm{H} / \mathrm{He}$ mice were immunized with Ad5, Ad5-pIX-ASP-M, Ad5-gp83 or together with Ad5gp83 + Ad5-pIX-ASP-M, according to the immunization schedule depicted in Figure 5A. Two weeks after boost, mice were injected with a lethal dose of blood trypomastigotes. Mice immunized with vector Ad5-pIX-ASP-M, Ad5-gp83 or together with Ad5-gp83+ Ad5-pIX-ASP-M and challenged with a lethal dose of T. cruzi blood trypomastigotes. Mice immunized with vector Ad5-pIX-ASP-M showed $\sim 60 \%$ reduction in parasitemia whereas mice immunized with the Ad5gp83 vector showed $\sim 70 \%$ reduction compared with the mice immunized with Ad5 alone. Interestingly, mice immunized with Ad5-gp83 + Ad5-pIX-ASP-M and challenged with a lethal dose of T. cruzi blood trypomastigotes presented the most parasitemia reduction at $\sim 80 \%$ with respect to the mice group that received Ad5 vector alone (Figure 5B).

Mice that were immunized with Ad5-pIX-ASP-M, Ad5-gp83, or Ad5-gp83 + Ad5-pIX-ASP-M were able to prolong survival after T. cruzi challenge compared with mice immunized with Ad5 alone. However, mice co-immunized with a vector containing an amastigote surface epitope (Ad5-pIX-ASP-M) and a vector containing a trypomastigote surface epitope (Ad5-gp83), exhibited a higher survival rate among the immunized groups (Figure $5 \mathrm{C}$ ). Neutralizing antibodies obtained after immunization from the various groups of mice were able to control or reduce infection of cardiomyocytes by T. cruzi as compared with the Ad5-pIX-ASP-M or Ad5 vaccinated or control mice (Figure 6A and 6B). Mice immunization with Ad5-gp83 induces potent neutralizing antibodies (Figure 6), whereas immunization with Ad5-pIX-ASP-M only induced strong CD8 ${ }^{+}$ responses (Figure 4C and 4F). However, co-immunizing mice with Ad5-gp83 and Ad5-pIXASP-M induced neutralizing antibodies (induced by Ad5-gp83) (Figure 6) and strong specific $\mathrm{CD}^{+}$responses induced by Ad5-pIX-ASP-M (Figure 4C and 4F). 
A.
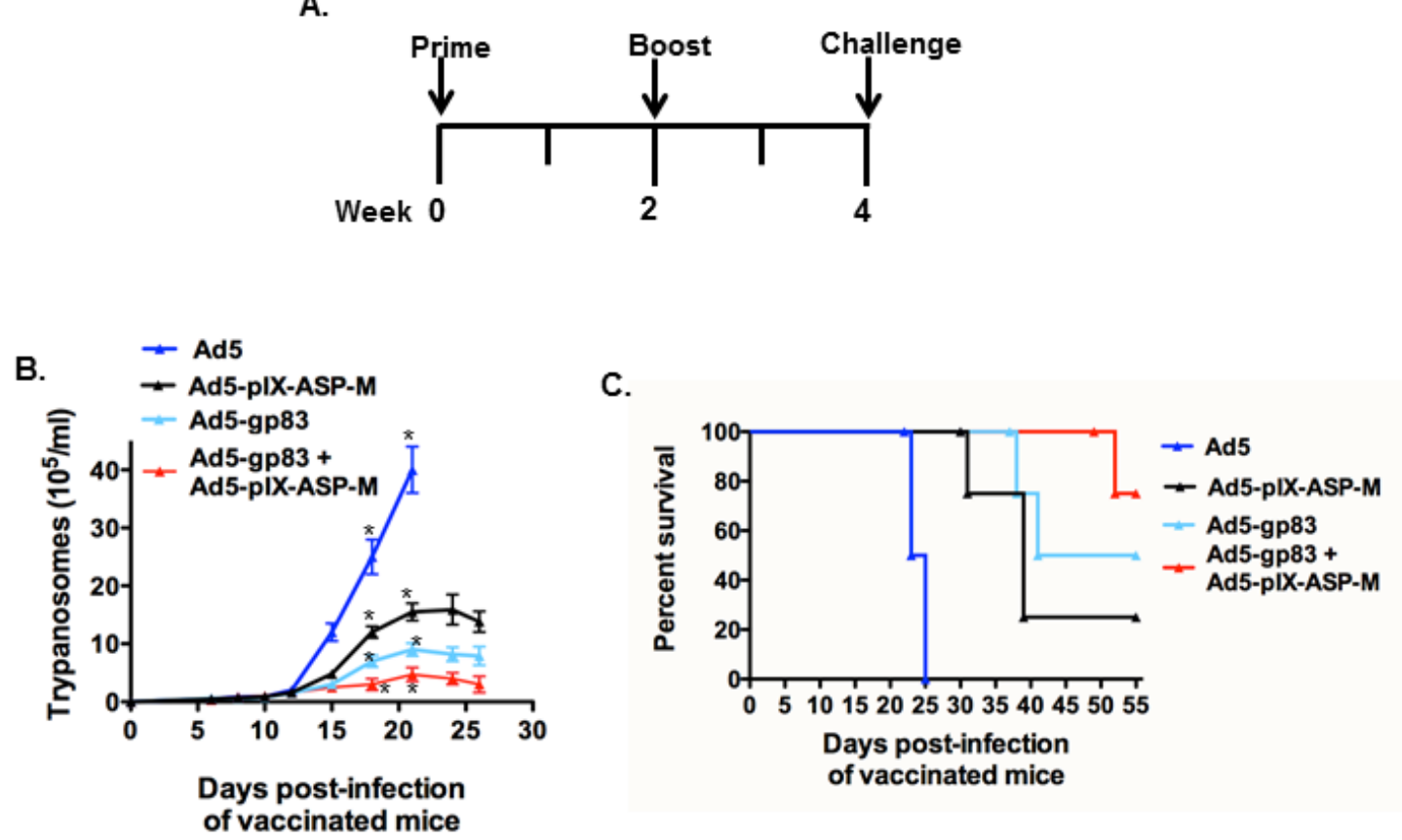

Figure 5. Immunization of mice with Ad5-pIX-ASP-M provides protection against challenge with T. cruzi, and this protection is significantly increased when mice are co-immunized with Ad5-pIXASP-M and Ad5-gp83. (A): Schedule of immunization and challenge with T. cruzi trypomastigotes. (B) Parasitemia of vaccinated mice with several vaccine Ad vector constructs. $\mathrm{C} 3 \mathrm{H} / \mathrm{He}$ mice (5 per group, 6-week-old) were immunized with Ad5, Ad5-pIX-ASP-M, Ad5-gp83 or with Ad5-gp83 + Ad5-pIXASP-M and challenged intraperitoneally with a lethal dose of blood trypomastigotes $\left(5 \times 10^{3}\right)$. The kinetics of parasitemia was determined in $5 \mu \mathrm{l}$ of blood tail. Data represent the mean values \pm SEM. The means are significantly different $(P<0.0229)$ among the 4 groups at the times indicated by 1 -way ANOVA. $(C)$ : Kaplan-Meier survival plot. 
A.

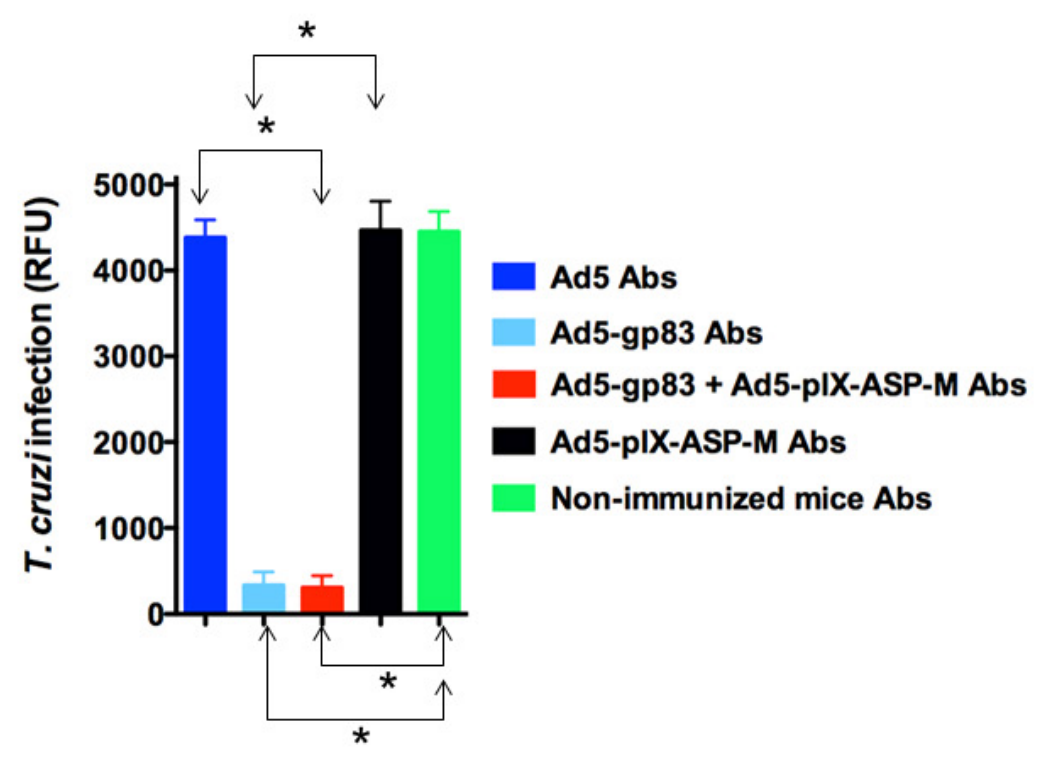

B.
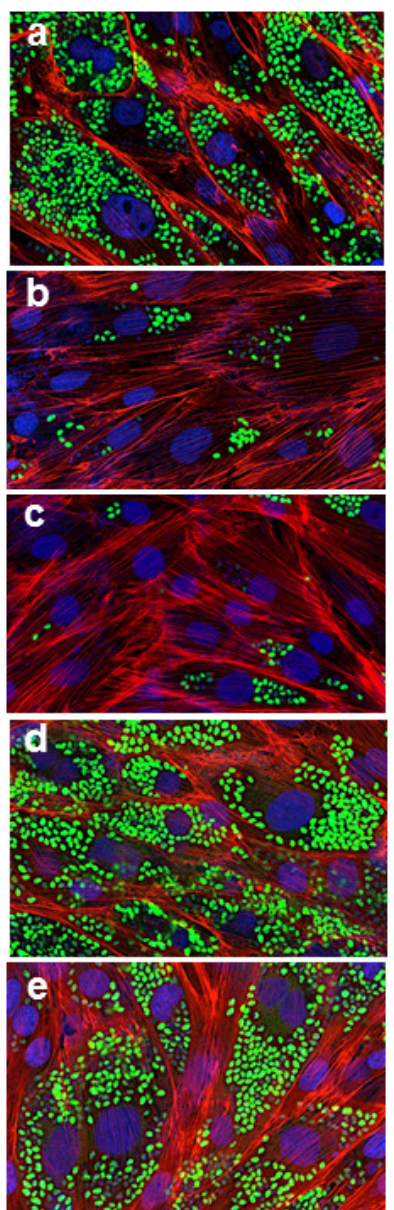

Figure 6. Mice co-immunized with Ad5-pIX-ASP-M and Ad5-gp83 induce neutralizing antibodies. (A): Neutralization of T. cruzi infection of cardiomyocytes with Abs from vaccinated mice with Ad5, Ad5-gp83, Ad5-gp83 + Ad5pIX-ASP-M, Ad5-pIX-ASP-M, or with Abs from nonimmunized mice. Parasite multiplication within cell monolayers was estimated by determining the fluorescence level of parasites expressing green fluorescence protein, which is indicated as relative fluorescence units (RFU) at $72 \mathrm{~h}$ of infection. Data represent the mean values \pm SEM of results from triplicate samples. $\left.{ }^{*}\right)=P<0.0001$ by 1 -way ANOVA. (B): Fluorescence microscopic observation of the effect of neutralizing antibodies on cardiomyocyte infection by T. cruzi. Trypomastigotes expressing GFP were pre-treated with Abs from mice vaccinated with Ad5 (a), Ad5-gp83 (b), Ad5-gp83 + Ad5-pIX-ASP-M (c), Ad5-pIX-ASP-M (d), or with Abs from nonimmunized mice (e) and exposed to cardiomyocytes for $72 \mathrm{~h}$ as described in Material and Methods. Abs were obtained from mice injected with either vaccine constructs or with Abs from nonimmunized mice before T. cruzi challenge. GFP-expressing amastigotes are seen inside host cells, host cell nuclei are stained blue, and cellular actin filaments are stained red.

\section{DISCUSSION}

A safe and effective vaccine against T. cruzi has long been in demand, but has been elusive thus far. Here we demonstrate that the T. cruzi epitope capsid-incorporation strategy is a new approach for Chagas vaccine development. 
In this study we examine the $\mathrm{CD}^{+}$responses to the T. cruzi amastigote ASP-M epitope that was incorporated into the Ad5 pIX to evaluate whether this vaccine elicits an immune protective response. The insertion of the ASP-M epitope did not affect pIX; major capsid proteins, such as fiber; or the overall fitness of the vector as we previously described for the incorporation of gp83 [22]. The modified vector had normal growth characteristics similar to the wild type Ad5. The insertion of the ASP-M epitope yielded surface exposure as demonstrated by whole-virus ELISA assay. In this study, we also examined the vaccine efficacy of co-immunizing mice with Ad5-pIX-ASP-M carrying the amastigote ASP-M epitope and the Ad5-gp83 carrying the trypomastigote gp83 neutralizing epitope, a vaccine strategy that has not been previously carried out for T. cruzi.

Previously, we examined the humoral responses to the T. cruzi gp83-epitope that was capsid-incorporated on Ad5 vectors where we generated a recombinant Ad5 vector with an epitope derived from T. cruzi [22]. This gp83 epitope was incorporated into the HVR1 region of the major capsid protein hexon. Immunization with the T. cruzi capsid-modified vector (Ad5-gp83) elicits a robust neutralizing antibody response and reduces infection in murine experimental models for Chagas disease [22].

In this study we show that co-immunization of mice with the epitope capsid-incorporation strategy of invasive extracellular trypomastigotes and intracellular replicative amastigotes is effective at stimulating T. cruzi-specific effector $\mathrm{CD}^{+} \mathrm{T}$-cell responses as well as neutralizing antibodies that protect mice against $T$. cruzi infection by significantly reducing parasitemia and extending survival rates. This co-immunization induced $\mathrm{H}-2 \mathrm{~K}^{\mathrm{k}}$-restricted cytotoxic and interferon IFN $\gamma$ producing activated $\mathrm{CD}^{+}{ }^{+}$-cells, expressing TNFa and neutralizing antibodies. In this co-immunization strategy, the Ad5-pIX-ASP-M component of the vaccine induces intracellular IFN $\gamma$ expression, which is a marker of CD8 ${ }^{+} \mathrm{T}$-cell activation, and CD107a, which is a marker for cytotoxic function, and TNFa. Ad5-gp83, the other component of the vaccine, induces neutralizing antibodies. Thus, we suggest that co-immunizations with Ad5-pIX-ASP-M and Ad5-gp83 with both T. cruzi epitopes represent an advancement in the development of a Chagas vaccine.

Our results show that IFN $\gamma$ and TNFa expression by activated $\mathrm{CD}^{+}$cells may be required for effective clearance of T. cruzi, as demonstrated in transgenic models where lower numbers of IFN $\gamma$-producing $\mathrm{CD}^{+}$cells were unable to block replication of hepatitis B virus [38].

Our results also suggest that ASP-M-activated $\mathrm{CD}^{+} \mathrm{T}$ lymphocytes can reduce T. cruzi parasitism by secreting IFN $\gamma$ and TNFa. This may be consistent with studies suggesting that antigen-activated $\mathrm{CD}^{+} \mathrm{T}$ lymphocytes can eliminate or control viral infection by secretion of IFN $\gamma$ and TNFa [38-40].

A major obstacle to using Ad5 for vaccine therapy is that the majority of the population has pre-existing immunity (PEI) resulting from natural exposure to the common cold [41-44]. The antigen capsid-incorporation strategy to some degree can circumvent PEI in mice relative to boost and reboost [22]. One of our future strategies to circumvent PEI is to develop a chimeric Ad5 vector by replacing the entire Ad5 hexon with the hexon from Ad serotype 3 and to develop T. cruzi vaccine vectors from rare adenovirus serotypes (e.g., Ad3, Ad35, or Ad36) [45-47].

A protein level similarity search using BLASTP and TBLASTN was conducted against the UniProt database (http://www.uniprot.org) and NCBI RefSeq/genomes database (http://www.ncbi. 
nlm.nih.gov/refseq). We observed highly significant identity between the peptide epitope of gp83 and the ASP-M epitope to multiple geographically diverse T. cruzi strain proteins. Significant protein level similarity to the gp83 epitope was observed among T. cruzi strains from Brazil (CL Brener, Y, Sylvio, and Marinkellei), Argentina (CA1), Venezuela (Dm28C), Chile (Tulahuen), Bolivia (SO34 cL4), Colombia (Colombiana), and Mexico (MINOA). The amastigote epitope TEWETGQI presented statistically significant protein identity with proteins from T. cruzi strains from Brazil (CL Brener, Y, Brazil, Sylvio, G, Esmeraldo, and Marinkellei), Chile (Tulahuen), Colombia (Colombiana), and Venezuela (Dm28C and JR cl4). Furthermore, both epitopes are present in strains that are drug resistant, partially resistant, and susceptible. Thus, we suggest that both epitopes must be present in the development of molecular vaccines for Brazil, Chile, Venezuela, and Colombia and to cover infections caused by drug-resistant parasites that affect those countries.

We predicted that the ASP-M epitope binds to the HLA-A*32:05, HLA-A* 32:08, HLA-A* 02:87, HLA-A $A^{\star} 32: 06$, and HLA-A* $32: 20$, which are alleles frequent in Hispanic populations where Chagas disease occurs, and to 10 different HLA-A ${ }^{\star} 02$ and 32 alleles. After further genetic analysis (host and parasite), animal experimentation, and pathogen exposure history, there may be a precedent to administer this vaccine of similar vaccines to people in countries exposed to T. cruzi strains we identified here.

In summary, we demonstrated that co-immunizations with Ad5-pIX-ASP-M and Ad5-gp83 would be useful in the development of vaccines against Chagas disease, due to the ability of the vector to trigger robust ASP-M-activated $\mathrm{CD}^{+} \mathrm{T}$ lymphocytes that reduce T. cruzi parasitism by secreting IFN $\gamma$ and TNFa induced by Ad5-pIX-ASP-M and eliciting neutralizing antibodies via Ad5-gp83 to reduce parasitemia. The antigen capsid-incorporation strategy is attractive for a complex parasite such as T. cruzi, because the adenovirus capsid is extremely amenable to the incorporations of multiple linear and discontinuous epitopes of parasite antigens at various life cycles. Therefore, we suggest that this strategy can be manipulated to introduce T. cruzi epitopes of immunological importance to induce a robust anti-T. cruzi humoral and protective cellular response. Furthermore, our current study can be viewed as a platform to introduce an effective vaccine strategy for other infectious diseases.

\section{ACKNOWLEDGMENTS}

The authors are very grateful to Paul A. Goepfert and the Goepfert laboratory for their insightful discussions of this article.

\section{FINANCIAL SUPPORT}

This work was supported in part by National Institutes of Health grants 5R01AI089337-04 and UAB departmental funds (QLM), 5T32AI7493-18, AI080580, AI007281, HL007737, and MD007593 (FV), GM059994 (MFL), AI083925 (PNN). ALF was supported through the American Association of Immunologists Careers in Immunology Fellowship Program. UAB CFAR Flow Cytometry Core/Joint UAB Flow Cytometry Core are funded by NIH/NIAIDP30AI027767 and by NIH 5P30AR048311. The Confocal Microscopy Facility and the Bioinformatics Core used at Meharry were supported by National Institutes of Health grant MD007586. 


\section{POTENTIAL CONFLICTS OF INTEREST}

The funders had no role in study design, data collection and analysis, decision to publish, or preparation of the manuscript.

\section{REFERENCES}

1. Coura JR, Vinas PA. Chagas disease: a new worldwide challenge. Nature. 2010;465(7301):S6-7. PubMed PMID: 20571554. doi: 10.1038/nature09221

2. Tanowitz HB, Weiss LM, Montgomery SP. Chagas disease has now gone global. PLoS Negl Trop Dis. 2011;5(4):e1136. PubMed PMID: 21572510. Pubmed Central PMCID: 3082509. doi: 10.1371/journal.pntd.0001136

3. Hotez PJ, Dumonteil E, Betancourt Cravioto M, Bottazzi ME, Tapia-Conyer R, Meymandi S, Karunakara U, Ribeiro I, Cohen RM, Pecoul B. An unfolding tragedy of Chagas disease in North America. PLoS Negl Trop Dis. 2013;7(10):e2300. PubMed PMID: 24205411. Pubmed Central PMCID: 3814410. doi: 10.1371/journal.pntd.0002300

4. Lee BY, Bacon KM, Bottazzi ME, Hotez PJ. Global economic burden of Chagas disease: a computational simulation model. Lancet Infect Dis. 2013;13(4):342-8. PubMed PMID: 23395248. Pubmed Central PMCID: 3763184. doi: 10.1016/S14733099(13)70002-1

5. Chatelain E. Chagas disease drug discovery: toward a new era. J Biomol Screen. 2015;20(1):22-35. PubMed PMID: 25245987. doi: 10.1177/1087057114550585

6. Molina I, Gomez i Prat J, Salvador F, Trevino B, Sulleiro E, Serre N, Pou D, Roure S, Cabezos J, Valerio L, Blanco-Grau A, Sanchez-Montalva A, Vidal X, Pahissa A. Randomized trial of posaconazole and benznidazole for chronic Chagas' disease. $\mathrm{N}$ Engl J Med. 2014;370(20):1899-908. PubMed PMID: 24827034. doi: 10.1056/NEJMoa1313122

7. Villalta F, Dobish MC, Nde PN, Kleshchenko YY, Hargrove TY, Johnson CA, Waterman MR, Johnston JN, Lepesheva GI. VNI cures acute and chronic experimental Chagas disease. J Infect Dis. 2013;208(3):504-11. PubMed PMID: 23372180. Pubmed Central PMCID: 3698996. doi: 10.1093/infdis/jit042

8. Lepesheva GI, Hargrove TY, Rachakonda G, Wawrzak Z, Pomel S, Cojean S, Nde PN, Nes WD, Locuson CW, Calcutt MW, Waterman MR, Daniels JS, Loiseau PM, Villalta F. VFV as a New Effective CYP51 Structure-Derived Drug Candidate for Chagas Disease and Visceral Leishmaniasis. J Infect Dis. 2015;212(9):1439-48. PubMed PMID: 25883390. Pubmed Central PMCID: PMC4601915. doi: 10.1093/infdis/jiv228

9. Teixeira AR, Hecht MM, Guimaro MC, Sousa AO, Nitz N. Pathogenesis of chagas' disease: parasite persistence and autoimmunity. Clin Microbiol Rev. 2011;24(3):592630. PubMed PMID: 21734249. Pubmed Central PMCID: 3131057. doi: 10.1128/ CMR.00063-10

10. Rassi A, Jr., Rassi A, Marin-Neto JA. Chagas disease. Lancet. 2010;375(9723):1388402. PubMed PMID: 20399979. doi: 10.1016/S0140-6736(10)60061-X 
11. Marin-Neto JA, Cunha-Neto E, Maciel BC, Simoes MV. Pathogenesis of chronic Chagas heart disease. Circulation. 2007;115(9):1109-23. PubMed PMID: 17339569. doi: 10.1161/CIRCULATIONAHA.106.624296

12. Gutierrez FR, Guedes PM, Gazzinelli RT, Silva JS. The role of parasite persistence in pathogenesis of Chagas heart disease. Parasite Immunol. 2009;31(11):673-85. PubMed PMID: 19825107. doi: 10.1111/j.1365-3024.2009.01108.x

13. Girones N, Cuervo H, Fresno M. Trypanosoma cruzi-induced molecular mimicry and Chagas' disease. Curr Top Microbiol Immunol. 2005;296:89-123. PubMed PMID: 16323421 .

14. Iwai LK, Juliano MA, Juliano L, Kalil J, Cunha-Neto E. T-cell molecular mimicry in Chagas disease: identification and partial structural analysis of multiple cross-reactive epitopes between Trypanosoma cruzi B13 and cardiac myosin heavy chain. J Autoimmun. 2005;24(2):111-7. PubMed PMID: 15829403. doi: 10.1016/j.jaut.2005.01.006

15. Cunha-Neto E, Bilate AM, Hyland KV, Fonseca SG, Kalil J, Engman DM. Induction of cardiac autoimmunity in Chagas heart disease: a case for molecular mimicry. Autoimmunity. 2006;39(1):41-54. PubMed PMID: 16455581. doi: $10.1080 / 08916930500485002$

16. Lopes MF, DosReis GA. Trypanosoma cruzi-induced immunosuppression: selective triggering of $\mathrm{CD} 4+\mathrm{T}$-cell death by the T-cell receptor-CD3 pathway and not by the CD69 or Ly-6 activation pathway. Infect Immun. 1996;64(5):1559-64. PubMed PMID: 8613360. Pubmed Central PMCID: PMC173961.

17. Ouaissi A, Da Silva AC, Guevara AG, Borges M, Guilvard E. Trypanosoma cruzi-Induced Host Immune System Dysfunction: A Rationale for Parasite Immunosuppressive Factor(s) Encoding Gene Targeting. J Biomed Biotechnol. 2001;1(1):11-7. PubMed PMID: 12488621. Pubmed Central PMCID: PMC79673. doi: 10.1155/ S1110724301000055

18. Villalta F, Kierszenbaum F. Immunization against a challenge with insect vector, metacyclic forms of Trypanosoma cruzi simulating a natural infection. Am J Trop Med Hyg. 1983;32(2):273-6. PubMed PMID: 6404187.

19. Cazorla SI, Frank FM, Malchiodi EL. Vaccination approaches against Trypanosoma cruzi infection. Expert Rev Vaccines. 2009;8(7):921-35. PubMed PMID: 19538117. doi: 10.1586/erv.09.45

20. Dumonteil E, Bottazzi ME, Zhan B, Heffernan MJ, Jones K, Valenzuela JG, Kamhawi S, Ortega J, Rosales SP, Lee BY, Bacon KM, Fleischer B, Slingsby BT, Cravioto $\mathrm{MB}$, Tapia-Conyer R, Hotez PJ. Accelerating the development of a therapeutic vaccine for human Chagas disease: rationale and prospects. Expert Rev Vaccines. 2012;11(9):1043-55. PubMed PMID: 23151163. Pubmed Central PMCID: PMC3819810. doi: 10.1586/erv.12.85

21. Quijano-Hernandez I, Dumonteil E. Advances and challenges towards a vaccine against Chagas disease. Hum Vaccin. 2011;7(11):1184-91. PubMed PMID: 22048121. Pubmed Central PMCID: PMC3323496. doi: 10.4161/hv.7.11.17016 
22. Farrow AL, Rachakonda G, Gu L, Krendelchtchikova V, Nde PN, Pratap S, Lima MF, Villalta F, Matthews QL. Immunization with Hexon modified adenoviral vectors integrated with gp83 epitope provides protection against Trypanosoma cruzi infection. PLoS Negl Trop Dis. 2014;8(8):e3089. PubMed PMID: 25144771. Pubmed Central PMCID: 4140675. doi: 10.1371/journal.pntd.0003089

23. Villalta F, Smith CM, Ruiz-Ruano A, Lima MF. A ligand that Trypanosoma cruzi uses to bind to mammalian cells to initiate infection. FEBS Lett. 2001;505(3):383-8. PubMed PMID: 11576533.

24. Villalta F, Lima MF, Ruiz-Ruano A, Zhou L. Attachment of Trypanosoma cruzi to host cells: a monoclonal antibody recognizes a trypomastigote stage-specific epitope on the gp 83 required for parasite attachment. Biochem Biophys Res Commun. 1992;182(1):6-13. PubMed PMID: 1370617.

25. Pan AA, McMahon-Pratt D. Amastigote and epimastigote stage-specific components of Trypanosoma cruzi characterized by using monoclonal antibodies. Purification and molecular characterization of an 83-kilodalton amastigote protein. J Immunol. 1989;143(3):1001-8. PubMed PMID: 2501384.

26. Low HP, Tarleton RL. Molecular cloning of the gene encoding the $83 \mathrm{kDa}$ amastigote surface protein and its identification as a member of the Trypanosoma cruzi sialidase superfamily. Mol Biochem Parasitol. 1997;88(1-2):137-49. PubMed PMID: 9274875.

27. Low HP, Santos MA, Wizel B, Tarleton RL. Amastigote surface proteins of Trypanosoma cruzi are targets for CD8+ CTL. J Immunol. 1998;160(4):1817-23. PubMed PMID: 9469442.

28. Machado AV, Cardoso JE, Claser C, Rodrigues MM, Gazzinelli RT, Bruna-Romero O. Long-term protective immunity induced against Trypanosoma cruzi infection after vaccination with recombinant adenoviruses encoding amastigote surface protein-2 and trans-sialidase. Hum Gene Ther. 2006;17(9):898-908. PubMed PMID: 16972758. doi: 10.1089/hum.2006.17.898

29. Barbosa RP, Filho BG, Dos Santos LI, Junior PA, Marques PE, Pereira RV, Cara DC, Bruna-Romero O, Rodrigues MM, Gazzinelli RT, Machado AV. Vaccination using recombinants influenza and adenoviruses encoding amastigote surface protein-2 are highly effective on protection against Trypanosoma cruzi infection. PLoS One. 2013;8(4):e61795. PubMed PMID: 23637908. Pubmed Central PMCID: 3634828. doi: 10.1371/journal.pone.0061795

30. Lima MF, Villalta F. Trypanosoma cruzi trypomastigote clones differentially express a parasite cell adhesion molecule. Mol Biochem Parasitol. 1989;33(2):159-70. PubMed PMID: 2657421.

31. Lepesheva GI, Hargrove TY, Anderson S, Kleshchenko Y, Furtak V, Wawrzak Z, Villalta F, Waterman MR. Structural insights into inhibition of sterol 14alpha-demethylase in the human pathogen Trypanosoma cruzi. J Biol Chem. 2010;285(33):2558290. PubMed PMID: 20530488. Pubmed Central PMCID: 2919122. doi: 10.1074/jbc. M110.133215 
32. Matthews QL, Sibley DA, Wu H, Li J, Stoff-Khalili MA, Waehler R, Mathis JM, Curiel DT. Genetic incorporation of a herpes simplex virus type 1 thymidine kinase and firefly luciferase fusion into the adenovirus protein IX for functional display on the virion. Mol Imaging. 2006;5(4):510-9. PubMed PMID: 17150163. Pubmed Central PMCID: 1781529.

33. Gu L, Li ZC, Krendelchtchikov A, Krendelchtchikova V, Wu H, Matthews QL. Using multivalent adenoviral vectors for HIV vaccination. PLoS One. 2013;8(3):e60347.

PubMed PMID: 23555957. Pubmed Central PMCID: 3610663. doi: 10.1371/journal. pone.0060347

34. Wu H, Han T, Belousova N, Krasnykh V, Kashentseva E, Dmitriev I, Kataram M, Mahasreshti PJ, Curiel DT. Identification of sites in adenovirus hexon for foreign peptide incorporation. J Virol. 2005;79(6):3382-90. PubMed PMID: 15731232. Pubmed Central PMCID: 1075677. doi: 10.1128/JVI.79.6.3382-3390.2005

35. Johnson CA, Rachakonda G, Kleshchenko YY, Nde PN, Madison MN, Pratap S, Cardenas TC, Taylor C, Lima MF, Villalta F. Cellular response to Trypanosoma cruzi infection induces secretion of defensin alpha-1, which damages the flagellum, neutralizes trypanosome motility, and inhibits infection. Infect Immun. 2013;81(11):413948. PubMed PMID: 23980110. Pubmed Central PMCID: 3811821. doi: 10.1128/ IAI.01459-12

36. Araujo AF, de Alencar BC, Vasconcelos JR, Hiyane MI, Marinho CR, Penido ML, Boscardin SB, Hoft DF, Gazzinelli RT, Rodrigues MM. CD8+-T-cell-dependent control of Trypanosoma cruzi infection in a highly susceptible mouse strain after immunization with recombinant proteins based on amastigote surface protein 2. Infect Immun. 2005;73(9):6017-25. PubMed PMID: 16113322. Pubmed Central PMCID: PMC1231112. doi: 10.1128/IAI.73.9.6017-6025.2005

37. Sargent KL, Meulenbroek RA, Parks RJ. Activation of adenoviral gene expression by protein IX is not required for efficient virus replication. J Virol. 2004;78(10):5032-7. PubMed PMID: 15113884. Pubmed Central PMCID: PMC400331.

38. Guidotti LG, Ishikawa T, Hobbs MV, Matzke B, Schreiber R, Chisari FV. Intracellular inactivation of the hepatitis B virus by cytotoxic T lymphocytes. Immunity. 1996;4(1):25-36. PubMed PMID: 8574849.

39. Chyuan IT, Tsai HF, Tzeng HT, Sung CC, Wu CS, Chen PJ, Hsu PN. Tumor necrosis factor-alpha blockage therapy impairs hepatitis B viral clearance and enhances T-cell exhaustion in a mouse model. Cell Mol Immunol. 2015;12(3):317-25. PubMed PMID: 25661729. doi: 10.1038/cmi.2015.01

40. Kasahara S, Ando K, Saito K, Sekikawa K, Ito H, Ishikawa T, Ohnishi H, Seishima M, Kakumu S, Moriwaki H. Lack of tumor necrosis factor alpha induces impaired proliferation of hepatitis B virus-specific cytotoxic T lymphocytes. J Virol. 2003;77(4):246976. PubMed PMID: 12551985. Pubmed Central PMCID: 141095.

41. Thacker EE, Timares L, Matthews QL. Strategies to overcome host immunity to adenovirus vectors in vaccine development. Expert Rev Vaccines. 2009;8(6):761-77. PubMed PMID: 19485756. Pubmed Central PMCID: 3700409. 10.1586/erv.09.29 
42. Chirmule N, Propert K, Magosin S, Qian Y, Qian R, Wilson J. Immune responses to adenovirus and adeno-associated virus in humans. Gene Ther. 1999;6(9):1574-83. PubMed PMID: 10490767. doi: 10.1038/sj.gt.3300994

43. Schagen FH, Ossevoort M, Toes RE, Hoeben RC. Immune responses against adenoviral vectors and their transgene products: a review of strategies for evasion. Crit Rev Oncol Hematol. 2004;50(1):51-70. PubMed PMID: 15094159. doi: 10.1016/S10408428(03)00172-0

44. Zaiss AK, Machado HB, Herschman HR. The influence of innate and pre-existing immunity on adenovirus therapy. J Cell Biochem. 2009;108(4):778-90. PubMed PMID: 19711370. Pubmed Central PMCID: 2822460. doi: 10.1002/jcb.22328

45. Tian X, Su X, Li H, Li X, Zhou Z, Liu W, Zhou R. Construction and characterization of human adenovirus serotype 3 packaged by serotype 7 hexon. Virus Res. 2011;160(12):214-20. PubMed PMID: 21740937. doi: 10.1016/j.virusres.2011.06.017

46. Soloff AC, Liu X, Gao W, Day RD, Gambotto A, Barratt-Boyes SM. Adenovirus 5- and 35-based immunotherapy enhances the strength but not breadth or quality of immunity during chronic SIV infection. Eur J Immunol. 2009;39(9):2437-49. PubMed PMID: 19670380. doi: 10.1002/eji.200839130

47. Abbink P, Lemckert AA, Ewald BA, Lynch DM, Denholtz M, Smits S, Holterman L, Damen I, Vogels R, Thorner AR, O’Brien KL, Carville A, Mansfield KG, Goudsmit J, Havenga MJ, Barouch DH. Comparative seroprevalence and immunogenicity of six rare serotype recombinant adenovirus vaccine vectors from subgroups B and D. J Virol. 2007;81(9):4654-63. PubMed PMID: 17329340. Pubmed Central PMCID: 1900173. doi: 10.1128/JVI.02696-06

\section{COPYRIGHT}

(C) Pathogens and Immunity 2017

This work is licensed under a Creative Commons Attribution 4.0 International License. To view a copy of this license, visit http://creativecommons.org/licenses/by/4.0/ 